Spiegel, A. D. \& Becker, H. (2015). South Africa: anthropology or anthropologies? American

\title{
South Africa: anthropology or anthropologies?
}

\author{
Andrew D. Spiegel and Heike Becker
}

\section{Introduction}

A direct result of South Africa's specific history has been the extraordinary significance of its contested, if not conflicting, political and ideological positions on anthropology's South African trajectories. This was particularly true for the apartheid era between 1948 and the early 1990s when, as Robert Gordon and Andrew Spiegel (1993:86) have observed, South African anthropology had largely succumbed to apartheid as the dominant power in the country and in the region as a whole, with "its discourse perniciously dictating what should be written by both its supporters and, significantly, its opponents." Yet, as we demonstrate in this article, sociopolitical historical circumstances were momentous factors in the development of the discipline from its beginnings in South Africa in the early 1920s, and they continue to influence contemporary debates and practices.

South African anthropology-or, more precisely, South African social and cultural anthropology-was long divided ideologically, although the division was not immediately apparent when, in the 1920s, departments of anthropology were originally founded at the country's first universities. During that period, anthropology had a distinct section in the South African Association for the Advancement of Science, at which papers were presented by archaeologists, linguists, and anthropologists and ethnologists, with some being published in the South African Journal of Science. Today, however, and following a tendency among social-cultural anthropologists to be wary of doing work that might lead to their being described as "handmaidens of colonialism," the links with archaeology and linguistics have become quite tenuous-although, as some in both those disciplines begin to take on the challenges of working from a postcolonial perspective, there is growing potential for a new collaboration. That said, at the 16 universities at which the study of anthropology is offered, there are two departments that continue to include both sociocultural anthropologists and archaeologists and one at which linguistics has recently been attached to anthropology and both African studies and gender studies. More marked than the separation between the four fields of U.S. anthropology, however, have been divisions in South Africa between anthropology and ethnology, or what might be seen as two different anthropologies-divisions that became very stark particularly once the apartheid system and regime had taken hold in the 1940s. One may even ask whether certain contemporary tendencies among South Africa's anthropologists that have emerged during the 20 years since a post-apartheid state was constituted in the mid1990s may lead to a new division, as one colleague already suggested during a conference in 2001 regarding presentations with a decidedly pan-Africanist orientation (cf. Becker 2007:89). 


\section{Early Divisions}

One early branch of sociocultural anthropology in South Africa drew from British social anthropology following Alfred Radcliffe-Brown's founding, in 1921, of the country's first anthropology department at the English-medium University of Cape Town. It included many who were explicit in their rejection of apartheid and also of the preceding colonially inspired segregationist policies. Yet even into the 1950s when apartheid structures had already been entrenched, other social anthropologists were involved in compiling ethnological summaries for the national Department of Native Affairs' Ethnology Section; that is, they contributed to the state-sponsored and state-defined project of the "native question," which appeared during, and indeed before, the segregationist period of the 1930 and caused substantial disciplinary upheaval within anthropology (Lalu 2009).Early on, many social anthropologists demonstrated their rejection of segregationist policies in published work and public interventions. Due to the discipline's assigned field of expertise and particularly its concern with the concept of "culture" (and "cultures"), social anthropology leaned toward concepts of pluralism with which to engage the state from a liberal position; however, others- most prominently, perhaps, Max Gluckman but also Isaac Schapera (Gordon 1990:29)-reiterated Radcliffe-Brown's earlier assertion that South Africa had to be studied as a single society, with black and white people as component parts. Gluckman went further: he emphasized that African "societies" could not be understood outside the history of colonial conquest, capital accumulation, and racism (Cocks 2001).

Many from the social anthropology camp expressly took an anti-apartheid stance whether in their research and teaching or, for a few, in their civil society engagements. Among them, David Webster must be particularly noted; Webster was an anthropologist at the University of the Witwatersrand who was also a public activist and was assassinated by an apartheid agent in 1989.

The other branch-one that was based on a reading of pre-WWII German Völkerkunde and was variously described as volkekunde, ethnology, and cultural anthropologyadopted a perspective that fed directly into apartheid ideology (Kuper 2005). ${ }^{1}$ Volkekunde's key notion was "ethnos," which was understood as the equation of an essentialized "culture" with an ethnic group. A founding volkekundige (volkekunde scholar), Werner Eiselen, who, in 1926, established the first anthropology department at Stellenbosch University, an Afrikaans-medium university, went on to become the Permanent Secretary in the National Department of Native (later Bantu) Affairs and a central figure in designing apartheid alongside its most widely recognized architect, the former Stellenbosch Psychology and Sociology academic, Hendrik Verwoerd (HammondTooke 1997:65). Others among volkekunde's advocates were also directly complicit in both the design of apartheid structures and in various organs of the apartheid state, including, during apartheid's later years, the then-South African Defence Force, where they both trained recruits to "understand the enemy" and worked on the military's "hearts" and "minds" campaigns.

For the most part-albeit not entirely-the division between social anthropology and 
volkekunde paralleled the division between the country's English-medium and Afrikaansmedium universities. When, from the 1960 s onward, the apartheid government established new universities for exclusively black (but ethnically divided) students-in order to exclude the small number of black students from the older, now almost exclusively white English-medium universities-most of the anthropology taught at those new institutions tended to be volkekunde oriented, at least until the final years of the apartheid era. Most lecturers at the new ethnic universities, anthropologists included, came out of the Afrikaans-medium universities where volkekunde predominated. Moreover, the volkekunde approach was supportive of apartheid principles, including the Bantustan strategy of creating a separate so-called "homeland state" and a separate university for each supposedly distinctive "Bantu ethnos," as well as the primarily "Indian" and "Coloured" minority populations. ${ }^{2}$ This resonated with at least some students at the new ethnic universities who saw opportunity in that policy. In contrast, it was rejected by most South African social anthropology graduates who, therefore, did not seek appointments in these universities.

\section{A Central Influence from the Periphery}

Despite its peculiarities, which we discuss in this article, it would be wrong to regard South African anthropology, specifically social anthropology, as merely a derivative, or colonial outpost, of northern academies. Rather, the relationship with anthropology in the United Kingdom, and later also the United States, was one of intense mutual influence. While up until the late 1970 s British universities, most prominently among them Cambridge, remained the preferred destinations for South African doctoral candidates in social anthropology, and although Radcliffe-Brown was the first professor of the discipline in South Africa, already by the mid-2oth century the influence of South African- born anthropologists such as Meyer Fortes, Isaac Schapera, and Max Gluckman was substantial in the British academy; in later years, this extended to "younger" South Africans in the discipline such as Adam Kuper and, even more recently, Deborah James, among others. From the 1970s onward, anthropologists who received their initial training at South African universities have also been influential in the North American academy. Well-known among them are Jean Comaroff and John Comaroff and Namibian-born Rob Gordon, who, like many of his compatriots, had been trained as an undergraduate at the Afrikaans-medium Stellenbosch University. Many others emigrated to and became active anthropologists in other primarily Anglophone countries.

Unlike the earlier generations, South African anthropologists who left the country from the 1960s onward almost all did so in response to the depravities of apartheid as it unfolded at that time and, later, in response to the consequences of extreme inequality and high levels of violence that remain its legacy to the present day.

Among them were also a small number of black social anthropologists, including Archie Mafeje, who went into exile during the late 1960 of after having been shamefully denied a post at the University of Cape Town in 1968, despite a selection committee's recommendation that he be offered it. Other black social anthropologists who left for exile after having been political activists included Zacharia K. (better known as Z. K.) Matthews, who fled to Geneva and the World Council of Churches, and Livingstone 
Mqotsi, who ended up a high school principal in south-east London. Bernard Magubane, who was originally trained in sociology, was another who became a prominent voice after his appointment to an anthropology position in the United States.

The long history of intensive exchanges with the leading Anglo-Saxon nexus in anthropology has left a deep imprint on South African anthropology. Many practicing anthropologists and postgraduate students follow primarily debates in "international"that is, U.S. or U.K. academic contexts - and read and cite sources from these contexts. Engagements with other networks, including those on the African continent but also elsewhere in the world (e.g., in continental Europe, India, or China), remain generally at a very modest level.

\section{Institutionalizing the Divisions}

Although there had earlier been some co-operation between members of the volkekunde and social anthropology camps and although, in 1967, a committee was formed to oversee an annual anthropology conference in the country- always held at the distance-learning and, at that point, bilingual (English and Afrikaans) University of South Africa-tension between the two continued. Moreover, in 1977, after a few black anthropologists began attending the conference, the volkekunde camp established its own association. Known only by an Afrikaans-language moniker-Vereniging van Afrikaanse Volkekundiges (best translated as Association of Afrikaans Ethnologists)-it effectively excluded non-first language Afrikaans speakers from its membership as well as black South African Afrikaans-language speakers. The annual anthropology conference continued for another ten years until, in 1987, its activities led to the emergence of another association, the Association for Anthropology in Southern Africa (AASA). Although AASA claimed to open its doors to all anthropologists, it effectively excluded any apartheid supporters; indeed, it stigmatized them by requiring all aspirant members to subscribe to a clause in the preamble of its constitution that expressed an explicit rejection of apartheid. Many of the still few, but up-and-coming, black anthropologists from the apartheid state's relatively newly created universities for black students also attended the annual AASA conferences, which were effectively a continuation of the earlier anthropology conferences prior to there having been any anthropology associations in the country.

During the late apartheid era, South African anthropologists were mostly among themselves at their gatherings. This was a time during which the South African academy was subject, along with international sanctions against South Africa for its apartheid policy, to an academic boycott. Although it was highly contentious, the call for an academic boycott was supported by a significant number of South African social anthropologists, whose view was generally that "we will welcome any foreign visitor who is not permitted [by the state] to visit."

Despite new developments, for quite some time (although no longer now), volkekunde's influence remained significant in anthropology departments established in the black ethnic universities, which had been established by the apartheid state. However, it was steadily undermined both there and in a couple of the older Afrikaans-medium universities. The University of the Western Cape, originally designated as the ethnic 
university for "Coloured" students had turned to radical scholarship and activism in the 1980s; by the time apartheid came to an end, its anthropology lecturers included, among others, graduates of the radicalized social anthropology departments, some of whom subscribed to explicitly Marxist and feminist approaches. In the case of one quite-new White Afrikaans-medium institution, the anthropology department of the then Rand Afrikaans University, had, by the early 1980 s, completely rejected volkekunde, and the whole department's lecturing staff explicitly turned their backs on the approach in which they had all been trained. In the case of Stellenbosch University, home to the first volkekunde department, the department was closed down in the mid-1990s, and then, a couple of years later, social anthropology was introduced in the then Department of Sociology with the appointment of a senior South African social anthropologist.

Today one would be hard pressed to find any practicing anthropologist in South Africa who would formally self describe themselves as a volkekundige. Yet new forms of ethnoracial identity politics have emerged in anthropology as much as in discourses in the wider South African society. They tend to revolve around an often rather uncritical celebration of "anthropology at home" as the ostensibly ultimate antidote to the problem of alterity. The argument emphasizes an (essentialized) notion of "black" anthropologists' studies being fundamentally different in outlook from those of white researchers. This school of thought has little support among teaching academics. However, it has been growing recently among postgraduate students in anthropology. This African-nationalist line of argument is related to black identity political struggles against the powerfully othering legacy of colonialism and apartheid, a legacy that manifests in a search for an essential African-ness on which to build a foundation of black African dignity. Beyond anthropology departments, and in some instances within them, students, primarily at the historically white liberal English medium universities, have, throughout 2015, powerfully asserted claims to decolonization through successful struggles to remove symbols of the country's colonial past and intensive debates over curriculum change, both in anthropology and more broadly.

\section{Institutionalizing Reconciliation}

It was only ten years after the formal capitulation in 1990 of the apartheid regime, a time when calls for reconciliation in the country at large were widespread, that those linked with each of the two "branches" of the discipline came together to form a new unified association, Anthropology Southern Africa (ASnA). ASnA held its first annual conference in 2001 and was a founding member of the World Council of Anthropology Associations formed in 2004 in Brazil. In a sense, this moment marked the establishment of a new hegemony in South African anthropology, with volkekunde having been eclipsed by a broadly social-cultural anthropological perspective that was increasingly taking its lead from U.S. anthropology, although much of it was focused on pressing South African (and, to some extent, southern African) sociopolitical problems-which meant that it retained a particular kind of engaged focus, albeit one that has been primarily analytical rather than directly activist.

Yet, despite the present existence of a single anthropology association in the country, there continue to be fission lines both among South African anthropologists and within 
ASnA. The very few remaining volkekundiges have tended neither to become ASnA members nor to participate in the annual ASnA conferences that are hosted at various university campuses around South Africa and hopefully in the future more often elsewhere in the wider southern African region (previously an AASA conference was held in Zimbabwe in the late 1990 s and another one in 2000 in Namibia).

Today, the majority of ASnA conference participants are young and predominantly black anthropologists, almost all of them being postgraduate students, and a still small but growing number of faculty members in South African university anthropology programs that have adopted what might be called a social or sociocultural anthropology perspective. Their work tends to reveal a growing local hegemony that has been built upon what is dominant in the United States and the United Kingdom. A few of these younger members are also actively involved with other networks such as the European Association of Social Anthropologists (EASA) and with other anthropologists in continental Europe, and ASnA retains its links with the World Council of Anthropological Associations as well as the International Union of Anthropological and Ethnological Sciences.

As indicated above, at each conference over the past couple of years there has been some indication that a few relatively vocal members of the new generation of black southern African anthropologists and anthropology students are searching for an approach that can support their own engagement with black identity politics in the country and region. This emergent strand indeed may-or may not- turn in time to a perspective that will come to find significant aspects of the volkekunde approach both attractive and useful. That some of these younger South African anthropologists may seek to revive, or at least to reconstitute, an anthropology resembling that approach has come to raise some concern, rightly or wrongly, among those insisting on the pursuit of a critical anthropology, as it was constituted by earlier scholars such as Gluckman and promoted by the Marxistoriented anthropology of the late apartheid era (cf. Gordon and Spiegel 1993).

\section{Present Numbers}

A recent rough survey has sought to establish the numbers of personnel presently employed by South African universities to teach anthropology. Most noteworthy is that of 16 South African university departments that host anthropology courses and programs, only two remain exclusively autonomous and distinctive departments of anthropology, while two others are in joint departments with archaeology. The rest are located in various departments that ostensibly aim to associate anthropology with development studies, sociology, African studies, gender studies, linguistics, and, in one instance, indigenous knowledge systems-a field that has been embraced by some black academics who seek to find indigenous epistemologies in much the way that those engaged in black identity politics seem to be seeking ways to use the discipline to support their engagement.

The survey has also indicated a fluctuating total of around 75 or 80 individual anthropologists employed in primarily permanent tenured and a few short-term contract lecturing (including professorial) posts around the country, where they teach in anthropology programs or lead anthropology research projects. In addition the survey has 
indicated that 20 or 30 other professional anthropologists are employed at South African universities in nonanthropology teaching jobs or in high-level administrative jobs. Moreover, about 15 recently mandatorily retired professors continue to be involved in research and some in teaching on short-term contracts. In addition, the various universities host about 15 anthropology postdoctoral fellows, while a presently undeterminable number of others, some with doctoral degrees but most with master's degrees-a qualification that some universities still recognize as sufficient for a lecturing post - work as anthropologists in a variety of consultancies and NGOs around the country and region, as well as in various state-funded research institutions. A fairly large number of anthropology graduates with master's level qualifications also work in the media and culture industry. While these practicing anthropologists may well outnumber those in academic jobs, they have tended not to attend the annual ASnA conferences nor to become ASnA members, and there has been no systematic attempt to date to find them and catalogue them on a database, nor to design panels or programs at ASnA conferences specifically to accommodate their interests or to provide opportunities for their continuing education.

The total number of ASnA members tends to fluctuate quite markedly each year, partly because many postgraduate students become members only for a year or two while working on their dissertations (master's degree students are all required to do primary research and write a dissertation; and many present conference papers, some of which are published). In further part, it is because ASnA membership numbers are closely linked to attendance at ASnA conferences so that when conferences are held in less accessible venues or in venues perceived to be less desirable, they tend to attract fewer participants and thus fewer sign up for ASnA membership. In 2014, ASnA membership numbered just 142 (59 academics and professionals and 72 postgraduate students). In contrast, the figures for 2013 were 214 (98 academics and professionals, including various persons based outside the country and region, and 110 postgraduate students), and for 2012 they were 208 (92 academics and professionals and 110 postgraduate students).

\section{Fields of Research and Publication}

There has been a relatively newfound interest by many of those trained in the volkekunde tradition and by some black anthropologists based in historically black universities in heritage and tourism studies, often related specifically to the tourism industry and to its goal of providing ethnogaze opportunities. For some anthropologists, that interest reflects a new version of an old concern with salvage ethnography, now revitalized to contribute to a new interest in reconstructing images of what is increasingly being described as "indigeneity." Were the necessary links to be made, this approach might relate strongly to contemporary European folklore studies.

At present, South Africa-based sociocultural anthropologists conduct research on a wide range of topics. This is perhaps the first remarkable characteristic of contemporary South African anthropology: research is focused on thematic issues not on "traditional" or even contemporary "communities." Themes range from medical anthropology, which, due to the HIV/AIDS pandemic, has been considered particularly pressing, through development anthropology and the anthropology of development, to studies of urbanism, 
science and natural resources, conflict, violence (including the notorious, so-called xenophobic, violent attacks against African and Asian immigrants) and policing, human rights, identity politics and belonging, and popular culture. Relatively little attention is being paid to fields such as economic anthropology (the recent large-scale Human Economy project at the University of Pretoria is the exception), state formation, and religion and religious movements-the latter of which is rather surprising considering the enormous significance these movements have in the lives of most South Africans. Both religion and the state are phenomena whose South African manifestations have been studied extensively-but overwhelmingly by anthropologists based outside the country.

Almost all South Africa-based anthropologists will agree that social issues affecting South African society are central to anthropological research; there are disagreements, however, regarding epistemological and ideological approaches and, recently, about the empirical focus of ethnographic work that, from the discipline's local beginnings, was on black people. Today South African anthropologists generally work on understanding the complexities of human problems in what has turned out to be a somewhat-paradoxical new dispensation in which political liberation from the racist ethnicism of apartheid coincided with rampant socioeconomic liberalization. Some have turned to analyses of social suffering to demonstrate the effects of social, economic, and institutional power on the population's majority. As was the case with the neo-Marxist tradition in South African anthropology of the late apartheid era, poverty and socioeconomic inequality are finding central attention in social suffering. However, the links with calls for radical political and social change are somewhat more muted than in the past-a product of the fact that the present government has, until recently, managed to cast itself as the sole custodian of the liberation from apartheid and its legacies.

Three contentions have arisen in critiques by South Africa-based anthropologists of the attempt to reconceptualize an engaged anthropology in the present post-apartheid context through a focus on social suffering. The first relates to concerns over the approach's perspective on the subject of anthropological research in the post-apartheid era for its having apparently constructed black research subjects as racially "other" and as ostensibly passive, "suffering others" and of thereby reproducing the racialized inequalities of society at large (cf. Nyamnjoh 2012). Related to this are concerns that, although their number is growing, very few ethnographies have focused on white people's lives and that this in turn reproduces a long historical distinction between white researcher and black subject of anthropological research (Nyamnjoh 2012). The second contention is that emphasis on interpersonal relations of violence and suffering tend to direct attention away from a focus on the macrostructural conditions of capital and the postcolonial state (Becker 2007). The third argues that a focus on social suffering unduly narrows the theoretical and methodological scope of anthropology to social problems and thus precludes an in-depth analysis of the full range of human experience, as well as of innovative theorizing (Becker 2007; van Wyk 2012).

Although all local anthropological research occurs in a context of extreme racialized inequality, very little of it has studied up or provided ethnographies of the social and cultural dynamics of the "upper" social strata. At most they are considered in their 
relation to the "lower" strata of poorer people among whom the "real" problems are perceived to exist-problems that are in turn related to the country's and its neighbors' drive for "development" and that often generate research-funding opportunities. Relatively few anthropologists in South Africa are having to confront the challenges of studying up, such as those who have turned to focus their research on questions arising from the recently strident demands to transform the country's universities and their respective institutional cultures or climates to make them comfortable spaces for black students and academics. There are also those few who have attempted studies of local government or other local or regional-level institutional structures and their role in reproducing or addressing socioeconomic inequality. Thus far, there have been no published ethnographic studies of (old or new) elites in the country.

Almost all South African postgraduate and indeed professional academics' anthropological research today focuses on South African concerns; very few South Africabased anthropologists have conducted research beyond the borders of South Africa. However, as a slowly increasing number of students from elsewhere around the continent register at South African universities, problem-focused research about similar kinds of issues to those listed above, as they manifest in other African countries, is also beginning to be produced in master's and doctoral dissertations. The handful of research students from the Global North tend, for the most part, to focus on South African issues.

Until recently, the majority of doctoral dissertations tended not to be reworked for publication and remained accessible only through the respective holdings of university libraries, some of which have recently begun to make such documents available on open access systems. This has changed, however, as a new generation of anthropologists at South African universities has published monographs based on their doctoral dissertations over the past few years or are currently in the process of doing so.

In addition to the monographs drawing on doctoral research, anthropologists at South African universities publish mostly edited volumes and special theme collections in interdisciplinary and disciplinary journals in South Africa and abroad. The most noted recent volume, edited by immediate past ASnA president Leslie Bank and his brother Andrew Bank, a noted historian of South African anthropology, revisited the work of a leading mid-2oth century South African social anthropologist, Monica (Hunter) Wilsonher research, her students, and her legacy (Bank and Bank 2013). This collection also included chapters on Wilson's noted black students such the well-known Archie Mafeje as well as previously lesser-known figures such as Livingstone Mqotsi.

A highly significant place of publication for South Africa- based anthropologists has been the association's journal. Originally the then-volkekunde association's Tydskrif van Suid Afrikaanse Volkekunde (Afrikaans for Journal of South African Ethnology), the journal became the outlet of the new unified association and its name was changed to Anthropology Southern Africa in 2002. Thereafter, its focus also began slowly to change, although it took some years before volkekunde's influence over its editorial policy and practice had waned and a new editorial approach was introduced. 
This gained momentum in 2011 with the appointment of a new editor, Heike Becker, who has also guided the shift from a local publisher to Taylor and Francis, since 2014. The journal continues, as previously, to appear in two print double issues per year, although a new electronic format will split it into four single issues. Each issue now includes a thematic focus, usually guest edited; general feature articles; book reviews; and other smaller communications. The 2014 issues included special theme sections on "life, form, substance" and on "urbanity and mutuality"; the general articles reflected a broad thematic range, from explorations of masculinity in South African rugby after 1994 to landscape and complicity and the links between South African Jewry and Israel. Recently the journal has published articles on topics such as cities and urbanism, new religious movements, popular culture, social media, neoliberalism, nationalism, racism, social memory, protests and social movements, health and illness, and human rights.

The published articles are still largely based on research in South Africa, although work based on research in the neighboring South African Development Community (SADC) countries, elsewhere on the African continent, and, sometimes but rarely, beyond are increasingly being published. This follows the journal's active outreach to scholars who hail from or work in the wider southern African region. The journal's editorial board views southern Africa as a region that has been constituted through a web of uneven and unequal historical and present ties. Unlike in its earlier incarnation as the Tydskrif van Suid Afrikaanse Volkekunde, the journal today publishes in English only, although there have been discussions about possibly providing abstracts in Portuguese to accommodate readers in Angola and Mozambique.

A new editorial board was appointed in 2014 to support the journal's intended wider regional and international reach. It includes scholars based at institutions in South Africa and the wider southern African region while also reaching out to and attracting a range of international scholars who are engaged in southern African scholarship. These include South African and southern African-born anthropologists who are teaching and conducting research at institutions elsewhere as well as other scholars with a successful record of research on and in the region.

Connections between South Africa-based anthropologists and international colleagues vary considerably. Scholars based outside South Africa who have become actively involved in the journal as board members, reviewers, or authors are generally well considered by their South African colleagues, and various collaborations have recently developed. Moreover, the ASnA journal has been quite successful in its efforts at regionalization and linking anthropologists from and working in the wider southern African region. In contrast, the association's other activities, such as the annual conferences, have thus far remained almost entirely South Africa focused in terms of conference participants and the topics of papers presented. However, there have also been cases of open resentment toward anthropologists from abroad who have come to "collect data" in South Africa without seeking appropriate collegial connections with local anthropologists.

Some of the issues regarding regionalization originate in the history of the discipline of anthropology in much of Africa, especially beyond South Africa's borders. In other words, ASnA, and anthropology generally, faces the challenge of postcolonial academies' 
perceptions of anthropology as a hopelessly colonial science, particularly in Anglo-phone Africa. There has been consequent neglect in building the discipline in many African countries, including many in the southern African region such as Namibia, Botswana, Lesotho, Malawi, and Swaziland. This presents challenges for South African anthropologists, particularly given their growing concern to regionalize: How do we engage with scholarship in these countries that addresses matters that are of interest to anthropology, although it may not be produced by professional anthropologists and is often produced outside the universities? How do we encourage young anthropologists-intraining who hail from these countries but see no future for the discipline "back home"? Conversely, we are challenged to think about how and what South African anthropologists can learn from encounters with colleagues and students from other countries in southern Africa.

This seems particularly significant in the current sociopolitical circumstances in which southern African national boundaries have become much more porous than they were during the apartheid era. Despite a strong nationalist political rhetoric, people, goods and capital, and media and cultural forms today move quite readily across the region and the wider continent. As during earlier periods, socioeconomic and political developments provide significant challenges for South African anthropologists. In the current situation, this includes critical engagement with local issues; it also means looking beyond the country's borders, engaging more than previously in comparative research, and collaborating with colleagues in the other SADC countries and beyond. 


\section{Notes}

1. Volkekunde literally means knowledge about peoples, as in the German Völkerkunde.

2. "Coloured" was the apartheid era's hold-all category for all who were neither exclusively of and accepted as being of European descent and categorized sequentially as "European" and, later, "White" nor recognized as members of what were then described as "Bantu tribes" and categorized as "Native," then "Bantu," and later "Black." The category of "Coloured" included those of Chinese descent and descendants of indigenous huntergatherers and herders (Khoisan) and of imported slaves; persons of Indian descent were also included but as a subcategory. Under apartheid legislation, everyone was placed into one of three stipulated racial categories: Black, White, or Coloured, although from the late 1950 onward, in a range of legislative acts, "Indian" came to be treated as a distinct category, a distinction that continues to be politically salient in the present.

\section{References Cited}

Bank, Andrew, and Leslie J. Bank, eds. 2013 Inside African Anthropology: Monica Wilson and Her Interpreters. Cambridge: Cambridge University Press.

Becker, Heike 2007 De-Provincialising South African Anthropology: On Relevance, Public Culture and the Citizen Anthropologist. Anthropology Southern Africa 30(34):85-96.

Cocks, Paul 2001 Max Gluckman and the Critique of Segregation in South African Anthropology, 1921-1940. Journal of Southern African Studies 27(4):739-756.

Gordon, Robert 1990 Early Social Anthropology in South Africa. African Studies 49(1):15-48.

Gordon, Robert J., and Andrew Spiegel 1993 Southern Africa Revisited. Annual Review of Anthropology 22:83-105.

Hammond-Tooke, David W. 1997 Imperfect Interpreters: South Africa's Anthropologists, 1920-1990. Johannesburg: Witwatersrand University Press.

Kuper, Adam 2005 "Today We Have Naming of Parts": The Work of Anthropologists in Southern Africa. In Empires, Nations and Natives: Anthropology and State Making. Beno^ıt de L'Estoile, Federico Neiburg, and Lygia Sigaud, eds. Pp. 277299. Durham: Duke University Press.

Lalu, Premesh 2009 The Deaths of Hintsa: Postapartheid South Africa and the Shape of Recurring Pasts. Cape Town: Human Sciences Research Council Press.

Nyamnjoh, Francis B. 2012 Blinded by Sight: Divining the Future of Anthropology in Africa. Africa Spectrum 47(2-3):63-92.

Van Wyk, Ilana 2012 A Response. Anthropology Southern Africa 35(3-4):119-121.

\section{https://repository.uwc.ac.za/}

